\title{
Effect of bromocriptine and metoclopramide on serum prolactin levels in patients with amyotrophic lateral sclerosis
}

\author{
J SZULC-KUBERSKA,* H STĘPIEŃ, $†$ A KLIMEK,** D CIEŚLAK† \\ From the Department of Neurology* and Institute of Endocrinology, $\dagger$ Medical Academy of Lódź, Lódź, Poland
}

SUMMARY Secretion of prolactin in nine patients with amyotrophic lateral sclerosis and in seven healthy men was investigated with the use of metoclopramide stimulation and bromocriptine inhibition tests. Blood serum prolactin concentration was determined in the basal state and 30,60 and 120 minutes after oral administration of $10 \mathrm{mg}$ metoclopramide or $2.5 \mathrm{mg}$ bromocriptine. A period of 3 days intervened between testing each drug in the same individual. It was shown that basal prolactin levels in amyotrophic lateral sclerosis patients and the controls did not differ significantly, whereas in the metoclopramide stimulation test seven amyotrophic lateral sclerosis patients showed a very exaggerated response. The mean value of maximal prolactin increment was $1609.90 \%$ (SD 456 ) in comparison with the control group $638.3 \%$ (SD 89.7$)(p<0.01$ ). In the bromocriptine inhibition test the mean value of maximal prolactin percentage decrement was $50.4 \%$ (SD 6.1) in amyotrophic lateral sclerosis and 66.5\% (SD 5.3) in the controls and this difference was statistically insignificant. These data suggest that exaggerated prolactin response to metoclopramide in amyotrophic lateral sclerosis may be a result of a decreased activity of central dopaminergic neurons.

Amyotrophic lateral sclerosis is a progressive disease of the central nervous system involving motor neurons in spinal cord and cerebral cortex. Despite intensive studies, the pathogenesis is unknown and the treatment is still ineffective. A number of hypotheses for the damage to motor neurons have been postulated; viral infections, defects in the normal DNA repair mechanisms, heavy metal intoxication, immune system dysfunction ${ }^{1}$ are sometimes associated with motor neuron degeneration, but do not seem to be responsible for appearance of amyotrophic lateral sclerosis in its sporadic form. During recent years, particular attention has been focused on endocrine system dysfunction in the pathogenesis of amyotrophic lateral sclerosis. Some investigators have reported abnormal insulin, parathormone and thyroid hormone secretion in amyotrophic lateral patients. ${ }^{1}$ It has been found also that tissue and cere-

Address for reprint requests: Prof J Szulc-Kuberska, MD, Dept of Neurology, Medical Academy, 90-153 Lódź, Kopcińskiego, 22Str, Poland.

Received 11 August 1987 and in revised form 23 November 1987. Accepted 1 December 1987. brospinal fluid concentration of thyrotropin-releasing hormone (TRH) ${ }^{2}$ and corticotropin-releasing factor $(\mathrm{CRF})^{3}$ was lower in amyotrophic lateral sclerosis than in control patients. These findings have led to hypothesis that dysfunction of hypothalamic mediators could play some role in the motor neuron damage. Additional evidence in favour of such a possibility is the finding of decreased level of cerebrospinal fluid dopamine metabolites in patients suffering from amyotrophic lateral sclerosis. ${ }^{4}$ It is known that dopaminergic mechanisms have a major inhibitory effect on prolactin release ${ }^{56}$ and specific dopamine receptors which are capable of binding selective dopaminergic ligands have been demonstrated in hypothalamus and pituitary. ${ }^{7}$ We therefore studied the possible changes in prolactin secretion in amyotrophic lateral sclerosis patients using the dynamic tests with metoclopramide and bromocriptine.

\section{Methods}

The studies were performed in nine patients, aged from 52 to 70 years (mean 57.1), with a clinical diagnosis of amy- 
otrophic lateral sclerosis, confirmed by electrophysiological examination. The patients had no symptoms of any endocrine disease and routine skull radiographs were normal. The control group consisted of seven healthy men matched for age and weight. All the investigations were performed before the patients' treatment. Starting at 8.30-9.00 a.m., after an overnight fast and at least $1 \mathrm{~h}$ of bed rest, the patients received one tablet $(10 \mathrm{mg})$ of metoclopramide (Metoclopramidum-Polfa) or one tablet $(2.5 \mathrm{mg})$ of bromocriptine (Parlodel-Sandoz). Blood samples were obtained from the antecubital vein at $0,30,60$ and 120 min after the drug administration. A period of 3 days intervened between tests of each drug in the same individual. Plasma was separated, frozen and stored at $-20^{\circ} \mathrm{C}$ until assayed. Serum prolactin levels were determined by a double-antibody technique using RIA kits obtained from Serono Diagnostics, Switzerland. All assays were performed in duplicate within the same run. The lower limit of assay sensitivity was 2 $\mathrm{ng} / \mathrm{ml}$. The intra- and interassay coefficients of variance were less than $6 \%$ and $10 \%$, respectively. Statistical analysis was performed by Student's $t$ test.

\section{Results}

The detailed results of metoclopramide stimulating test in amyotrophic lateral sclerosis patients and seven healthy men are shown in the fig. The basal prolactin levels in all amyotrophic lateral sclerosis patients were in the normal range (between 3.3-14.2 $\mathrm{ng} / \mathrm{ml}$ ) and were not significantly different in the control group. The peak response occurred at $60 \mathrm{~min}$ after metoclopramide administration in both investigated groups. However, in amyotrophic lateral sclerosis patients the mean value of maximal prolactin

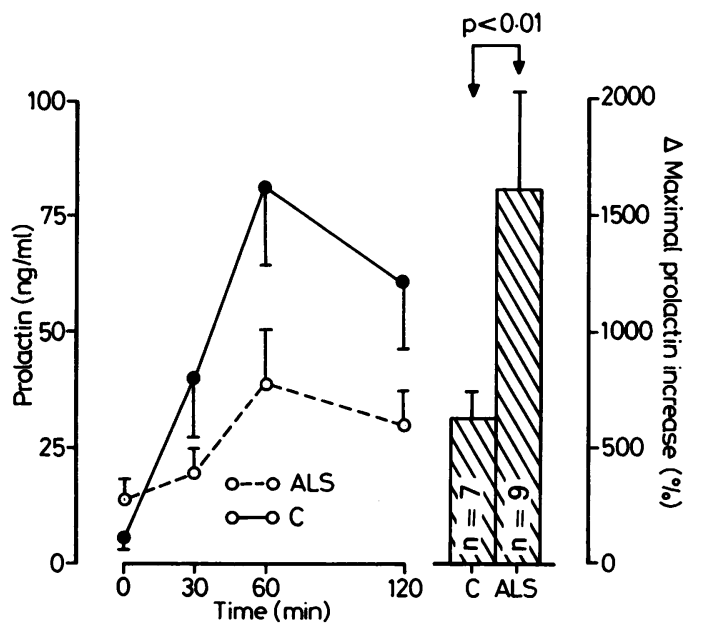

Fig Prolactin levels $(\mathrm{ng} / \mathrm{ml})$ in patients with amyotrophic lateral sclerosis (ALS) and in the control group (C) in metoclopramide stimulatory test. The data represent the means, and vertical lines indicate 1 SEM $n=$ number of patients.
Table Prolactin levels $(\mathrm{ng} / \mathrm{ml})$ in patients with amyotrophic lateral sclerosis in bromocriptine inhibiting test

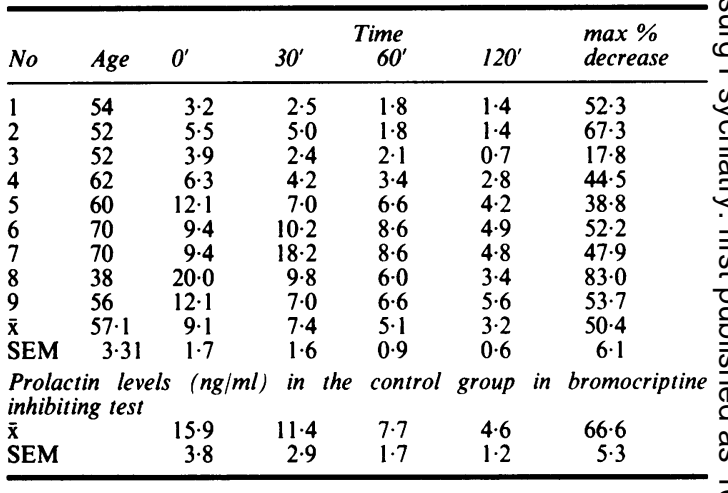

increment was significantly greater after met- $\overrightarrow{\vec{\omega}}$ oclopramide administration (1609.9\% SEM 456) as $\stackrel{9}{S}$ compared with controls (638.3 SEM 89.7) ( $\mathrm{p}<0.01)$. It is noteworthy that seven amyotrophic lateral sclerosis patients showed a very exaggerated response $\stackrel{0}{-}$ to the drug (increase higher than $700 \%$ ) which indi- ir cated a "functional" hyperprolactinaemia.

The results of dynamic changes of prolactin secretion in the bromocriptine inhibiting test are presented in the table. Bromocriptine suppressed serum pros $\vec{z}$ lactin levels in both tested groups with maxima inhibitory effect $120 \mathrm{~min}$ after the administration the drug. The mean value of maximal serum prolacti $\vec{\oplus}$ decrement in amyotrophic lateral sclerosis patien was $50.4 \%$ (SEM 6.1) and in comparison was not significantly different from the controls $(66 \cdot 5$, SEM $5 \cdot 3)$.

\section{Discussion}

We were able to confirm that metoclopramide is a $\frac{0}{3}$ potent stimulator of prolactin secretion not only in healthy men ${ }^{89}$ but also in patients with amyotrophic lateral sclerosis. Metoclopramide is classified as a dopamine $\mathrm{D}_{2}$ receptor blocker which causes prolactin release primarily by inhibiting the dopamine-induced hypothalamic secretion of prolactin inhibiting factor 3 or a stimulatory effect on the release of a still unidentified prolactin releasing factor. ${ }^{10}$ Bro- $\frac{O}{3}$ mocriptine, a $\mathrm{D}_{2}$ dopamine receptor agonist, inhibiting normal and inappropriate lactation by inhibiting prolactin release at the level of pituitary $\frac{D}{0}$ lactotrophs. ${ }^{1112}$ On the other hand central sites of action are indicated by observations such as the slow- N ing of dopamine turnover in the tuberoinfundibular $N$ neurons, ${ }^{13}$ which can be interpreted as the hypo- $N$ thalamic effect of the prolactin inhibitory action of $\omega$ bromocriptine. The finding of exaggerated prolactin response to metoclopramide indicates a "functional" 
Effect of bromocriptine and metoclopramide on serum prolactin levels in patients with amyotrophic lateral sclerosis

hyperprolactinaemia ${ }^{1415}$ and could imply the existence of altered central dopamine neurotransmission in amyotrophic lateral sclerosis. It is possible that a lower level of hypothalamic dopamine could lead to deficient prolactin inhibition factor secretion and thereby to elevation of prolactin levels, but the direct neurochemical evidence for the existence of alterations in the dopaminergic transmission associated with amyotrophic lateral sclerosis is still lacking. However, recent studies have demonstrated several neurotransmitter-neuromodulator abnormalities in the central nervous system of amyotrophic lateral sclerosis patients. ${ }^{316}$ Whitehouse et $\mathrm{ll}^{17}$ found a distinct reduction of glycine and muscarinic receptors density in upper and spinal cord motor neurons in amyotrophic lateral sclerosis. Appel ${ }^{18}$ suggested that amyotrophic lateral sclerosis is a consequence of changes in the levels of specific neurotrophic hormones and postulated the same aetiopathogenesis for Alzheimer's and Parkinson's diseases. These studies suggest that a single neurochemical lesion hypothesis in amyotrophic lateral sclerosis may be insufficient.

In conclusion, our results have indicated that exaggerated prolactin response to metoclopramide may be a result of a decreased activity of central dopaminergic neurons and may give same direction to future neuroendocrinological research in amyotrophic lateral sclerosis.

We thank Ms H. Pisarek for excellent technical assistance.

This work is partially supported by M.Z.V.-R.31

\section{References}

1 Tanden R, Bradley WG. Amyotrophic lateral sclerosis: Part 2. etiopathogenesis. Ann Neurol 1985;18:419-31.

2 Engel WK, Sidique T, Nicoloff JT. Effect on weakness and spasticity in amyotrophic lateral sclerosis of thyrotropin-releasing hormone. Lancet 1983;ii:73-5.

3 Klimek A, Cieślak D, Szulc-Kuberska J, Stępień H. Reduced lumbar cerebrospinal fluid corticotropin releasing factor levels in amyotrophic lateral sclerosis. Acta Neurol Scand 1986;74:72-4.
4 Mendell JR, Chase TN, Engel WK. Amyotrophic lateral sclerosis. A study of central metabolism and therapeutic trial of levodopa. Arch Neurol 1971;25:320-25.

5 Boyd AE, Reichlin S. Neurol Control of prolactin secretion in man. Psychoneuroendocrinology 1978;3:113-30.

6 Ben-Jonathan N. Dopamine: A prolactin-inhibiting hormone. Endocr Rev 1985;6:564-89.

7 Brown GH, Seeman P, Lee T. Dopamine-neuroleptic receptors in basal hypothalamus and pituitary. Endocrinology 1976;99:1407-10.

8 McNeilly AS, Thorner ME, Volans E, Besser GM. Metoclopramide and prolactin. Br Med J 1974;2:729.

9 McCallum RW, Sowers JR, Hershman JR, Sturdenvant AL. Metoclopramide stimulates prolactin secretion in man. J Clin Endocrinol Metab 1976;42:1148-51.

10 Sowers JR, McCallum RW, Hershman JR, Carlson HE, Sturdenvant AL, Meyer N. Comparison of metoclopramide with other dynamic test of prolactin secretion. J Clin Endocrinol Metab 1976;43:679-81.

11 Del Pozo E, Varga L, Wyss $\mathrm{H}$, et al. Clinical and hormonal responses to bromocriptine/BC-154/ in the galactorrhoea syndromes. J Clin Endocrinol Metab 1974;89:774-84.

12 Flückiger E, Marko M, Doepfner N, Niederer W. Effect of ergot alkaloids on the hypothalamic-pituitary axis. Postgrad Med J 1976;52/suppl 1/:57-61.

13 Hökfelt T, Fuxe K. Effect of prolactin and ergot alkaliods on the tuber-infundibular dopamine/DA/ neurons. Neuroendocrinology 1972;9:100-22.

14 Jeske $W$. The effect of metoclopramide, TRH and LDOPA on prolactin secretion in pituitary adenoma and in "functional galactorrhoea syndrome". Acta Endocrinol (Copenh) 1979;91:385-92.

15 Pawlikowski M, Komorowski J, Owczarczyk I. Blood serum prolactin levels in basal conditions and after metoclopramide stimulation in women with galactorrhoea and in patients with pituitary tumors. Endokrynologia Pol 1983;34:235-43.

16 Cieślak D, Szulc-Kuberska J, Stępień H, Klimek A. Epidermal growth factor in human cerebrospinal fluid: reduced levels in amyotrophic lateral sclerosis. $J \mathrm{Neu}$ rol 1986;233:376-7.

17 Whitehouse PJ, Wamsley JK, Zarbin MA, Price DL, Tourtelotte WW, Kuhar MJ. Amyotrophic lateral sclerosis: alterations in neurotransmitter receptor. Ann Neurol 1983;14:8-16.

18 Appel SH. A unifying hypothesis for the cause of amyotrophic lateral sclerosis, parkinsonism, and Alzheimer disease. Ann Neurol 1981;10:499-505. 